\title{
JATROPHA CURCAS PLANT AS A POTENTIAL BIODIESEL FEEDSTOCK IN INDONESIA
}

\author{
Fadjar Goembira and Taufiq Ihsan \\ Air Quality Laboratory Department of Environmental Engineering Andalas University \\ Email address: fgoembira@ft.unand.ac.id
}

\begin{abstract}
One of the alternatives for biodiesel feedstock is oil from Jatropha curcas plant. The advantages of using this plant are due to its ability to grow in poor soils, different parts of the plant can also be used for different purposes, the by products of biodiesel productions have economic values, and biodiesel is more environmentally friendly when it is being produced and being used, compared to mineral derived oils. Although Indonesia has another alternative raw material for biodiesel production, i.e. palm oil, however the use of palm oil will affect its supply for the other sectors that have already established, e.g. for producing cooking oils. This situation will not happen to Jatropha curcas oil, due to its inedible characteristic.
\end{abstract}

Keywords: Biodiesel, Jatropha curcas, Indonesia

Salah satu alternatif untuk bahan baku biodiesel adalah minyak dari tanaman jarak. Keuntungan menggunakan tanaman ini adalah karena kemampuannya untuk tumbuh di tanah yang kurang subur, bagian lain dari tanaman ini juga dapat digunakan untuk tujuan yang berbeda, dengan hasil dari produksi biodiesel memiliki nilai ekonomi, dan biodiesel juga lebih ramah lingkungan ketika sedang diproduksi dan digunakan, dibandingkan dengan yang berasal dari minyak mineral. Meskipun Indonesia memiliki bahan baku alternatif lain untuk produksi biodiesel, yaitu minyak sawit, namun penggunaan minyak sawit akan mempengaruhi pasokan untuk sektor-sektor lain yang sudah mapan, misalnya untuk memproduksi minyak goreng. Situasi ini tak akan terjadi pada Jatropha curcas oil, karena tanamana ini tidak dapat dimakan.

Kata kunci: Biodiesel, Jatropha curcas, Indonesia 


\section{INTRODUCTION}

Diesel engine was invented in 1885 by Rudolf Christian Karl Diesel (1858-1830), and was firstly displayed to public in 1900 . Public was amazed by the ability of the engine to be run both by gasoline and peanut oil. In fact, the inventor stated in 1912 that "...the use of vegetable oils for engine fuels may seem insignificant today. But such oils may in the course of time become as important as petroleum and the coal tar products of present time".

Biodiesel is mono alkyl esters from fatty acid derived from plant oils, animal fats or used cooking oils, which is one of alternative fuels for petrodiesel. The most common biodiesel production process is by transesterification. Generally, chemical reaction formula of transesterification is as follows.

$$
\begin{array}{ll}
\mathrm{R}_{1} \mathrm{COOCH}_{3} & \mathrm{CH}_{2}-\mathrm{OH} \\
\mathrm{R}_{2} \mathrm{COOCH}_{3} & +\quad \mathrm{C} H-\mathrm{OH} \\
\mathrm{R}_{3} \mathrm{COOCH}_{3} & 1 \\
& \mathrm{CH}_{2}-\mathrm{OH}
\end{array}
$$

Fatty acid methyl esters $\quad$ Glycerol (FAME)
Although at present the use of mineral derived diesel fuel is the majority, however there is an increase concern on using biodiesel. This is due to the recent economic (i.e. high world price oils), and environmental (Global Warming) concerns. Biodiesel is a substitute for, or an additive to, the conventional diesel fuel. This alternative fuel can be derived from plantations, e.g. sunflower, rapeseed, canola, coconut palm, and jatropha.

From reaction formula (1), it can be seen that triglyceride, which is the main component in raw materials, is reacted with methanol with the help of alkali catalysts (commonly $\mathrm{NaOH}$ or $\mathrm{KOH}$ ) to produce Fatty Acid Methyl Esters (FAME) that is biodiesel. Glycerol is a by-product from the transesterification reaction.

There are some advantages of biodiesel utilization, i.e.:

- Biodiesel can be produced from renewable resources (Janaun and Ellis, 2010);
- Biodiesel can be used directly on diesel engines, without the need for any modifications. It can be used individually or as a blend with petrodiesel (Lapuerta et al., 2008);

- The use of biodiesel can reduce $\mathrm{CO}_{2}$ emission up to $78 \%$, as compared to the use of petrodiesel (Agarwal, 2007);

- Emission reduction of most air pollutants, i.e., carbon monoxide, hydrocarbon, particulate matter and smoke (Mittelbach et al., 1985; Haas et al., 2001; Sahoo et al., 2009; Tan et al., 2012; Ozsezen et al., 2009);

- Other advantages as compared to petrodiesel: more biodegradable (Sendzikiene et al., 2007), lower toxicity (USEPA, 2002), much lower sulfur content (Mittelbach et al., 1985), lubricating effect on engine and higher flash point thereby safer for storing and transporting (Labeckas and Slavinskas, 2006). 


\section{ABOUT JATROPHA CURCAS PLANT}

Jatropha curcas plant is originally from the American continent. This plant is usually available in all tropical and sub tropical areas, and has over 200 names worldwide and various uses. Some of the names are physic nut (English), pugernoot (Dutch), pignon d'Inde (French), sabudam (Thai), kadam (Nepalese), and tubing-bakod (Filipino). Usually people use this plant to fence their crop lands, because this plant is not consumed by animals. The bark is grey and exudes whitish coloured, watery latex when cut. Jatropha curcas plant sheds their leaves once a year and grows very fast that can attain a height of around 4 metres in 4 5 years, although in some cases can reach up to eight or ten meters under favourable conditions. After two years of plantation, it starts to produce fruits. The fruit of Jatropha curcas plant is capsule shaped which initially green coloured, but turns yellow and finally becomes black after ripening. Each fruit consists of 3 to 4 seeds that can be produced by the plant up to 50 years. From 1 $\mathrm{kg}$ of fruit there are 1,200 to 1,500 seeds.

According to Tickell (2000), actually there are some other plants beside Jatropha curcas plant that can also produce vegetable oils. The following table shows various types of the plant together with the amount of possible extracted oil per hectare of the plants.

Table 1. Potential of Vegetable Oil Productions from Different Plants

\begin{tabular}{|l|l|r|l|l|r|}
\hline Plant & \multicolumn{1}{|c|}{ Latin Name } & $\begin{array}{c}\text { kg oil per } \\
\text { hectare }\end{array}$ & Plant & Latin Name & $\begin{array}{c}\text { kg oil per } \\
\text { hectare }\end{array}$ \\
\hline Corn & Zea mays & 145 & Rapeseed & Brassica napus & 1,000 \\
\hline Oat & Avena sativa & 183 & Olive & Olea europaea & 1,019 \\
\hline Cotton & Gossypium hirsutum & 273 & Physic nut & Jatropha curcas & 1,590 \\
\hline Soybean & Glycine max & 375 & Coconut & Cocos nucifera & 2,260 \\
\hline Peanut & Arachis hypogaea & 890 & Oil palm & Elaies guineensis & 5,000 \\
\hline
\end{tabular}

Source: Tickell, 2000

Although there are some plantations that produce more oils than Jatropha curcas, however those oils are edible. This means that there will be a competition in using those oils if their availability is less than their demands. In this situation, Jatropha curcas oil which contain trace of toxins thus makes it inedible is better for producing biodiesel.

Furthermore, Jatropha curcas is not only known for its potential to produce oil. Although many people focus on using the oil of this plant, however almost all parts of the plant are usable. Following are the specific utilizations of Jatropha curcas plant.

\section{JATROPHA CURCAS PLANTATION}

The Jatropha curcas plant grows almost everywhere, even on gravely, sandy, and saline soils. This plant can be grown in a nursery by its stems or seeds, and it can be planted in marginal/poor soil areas because it is one of drought resistant plants. It has been successfully grown in dry regions with annual rainfall of $300-1,000 \mathrm{~mm}$. The plant sheds most of its leaves to reduce transpiration loss, thus making it drought resistant. Suitable altitudes are from $0-500$ $\mathrm{m}$ and preferred temperature is above $20^{\circ} \mathrm{C}$, 
Table 2. Utilization of Jatropha curcas Plant

\begin{tabular}{|c|c|c|c|c|c|c|}
\hline Whole Plant & Root & Leaf & Latex & Seed & Barks & Twig \\
\hline $\begin{array}{l}\text { - Prevent } \\
\text { erosion } \\
\text { - Fence land } \\
\text { - Decoration } \\
\text { - Green } \\
\text { manure } \\
\text { - Prevent } \\
\text { desertificati } \\
\text { on }\end{array}$ & - Medicine & $\begin{array}{l}\text { - Medincine } \\
\text { (piles, } \\
\text { malaria) }\end{array}$ & $\begin{array}{l}\text { - Medicine } \\
\text { (cancer) } \\
\text { - For } \\
\text { making: } \\
\text { varnish, } \\
\text { ink }\end{array}$ & $\begin{array}{l}\text { - Oil } \\
\text { extraction } \\
\text { (up to } \\
37 \% \text { ) } \\
\text { For: } \\
\text { lighting or } \\
\text { diesel fuel, } \\
\text { lubricant } \\
\text { or } \\
\text { hydraulic } \\
\text { oil, } \\
\text { making: } \\
\text { insecticide, } \\
\text { soaps, } \\
\text { candles, } \\
\text { cosmetics. } \\
\text { - Cake for } \\
\text { fertilizer }\end{array}$ & $\begin{array}{l}\text { - Tanning } \\
\text { and } \\
\text { dyeing } \\
\text { material } \\
\text { s }\end{array}$ & $\begin{array}{l}\text { - Medicine } \\
\text { - Herbal } \\
\text { tooth } \\
\text { brush }\end{array}$ \\
\hline
\end{tabular}

Source: http://www.jatrophabiodiesel.org/jatrophaPlantation.php?_divid=menu2

although it also can grow in higher altitude with an ability to withstand a light frost. After two to five years, the plantation will produce seeds that annually yields from 2 to 12 tonnes per hectare depend on soil quality and

rainfall (http://www.jatrophabiodiesel.org/jatrophaPl antation.php?_divid=menu2). Following are some key factors that influence the oil yield of Jatropha curcas.

Table 3. Influencing Factors on Jatropha curcas Plantation

\begin{tabular}{|c|l|l|}
\hline No & \multicolumn{1}{|c|}{ Key Factor } & \multicolumn{1}{c|}{ Explanation } \\
\hline 1 & Climate & $\begin{array}{l}\text { Able to deal with severe heat, doing well in warmer areas. When cold it drops } \\
\text { its leaves. Can withstand light frost but not for long period of time. }\end{array}$ \\
\hline 2 & $\begin{array}{l}\text { Quality of the } \\
\text { Soil }\end{array}$ & $\begin{array}{l}\text { Best in sandy well-drained soils. Can cope with very poor soils and grow in } \\
\text { saline conditions. }\end{array}$ \\
\hline 3 & Irrigation & $\begin{array}{l}\text { Can handle dryness very well and possible to live almost entirely on humidity } \\
\text { in the air. Optimum rainfall for high yields from 600 to around 1,400 mm. }\end{array}$ \\
\hline 4 & Weeding & $\begin{array}{l}\text { With four times a year weeding, proper fertilization, surface ploughing and } \\
\text { pruning can yield around 15 - 20 kg of fruit per tree. }\end{array}$ \\
\hline 5 & Use of fertilizer & $\begin{array}{l}\text { For poor quality soils fertilizer containing small amount of calcium, } \\
\text { magnesium, and sulphur can increase yields. Can also use pressed cake from } \\
\text { oil extraction. }\end{array}$ \\
\hline 6 & Crop density & $\begin{array}{l}\text { Wider spacing can increase yields. However, 2 x 2 metres spacing should be } \\
\text { used for commercial plantation }\end{array}$ \\
\hline 7 & Inter-cropping & $\begin{array}{l}\text { No specific intolerance with other crops has been detected, thus can be inter- } \\
\text { cropped with various types of plant. }\end{array}$ \\
\hline
\end{tabular}

Source: http://www.jatrophabiodiesel.org/ 


\section{OIL EXTRACTION FROM JATROPHA}

\section{CURCAS SEEDS}

Oil is very easily extracted from Jatropha curcas seeds by using a presser-expeller. There are various types of the presser- expeller, from the simplest ones that are hand driven expellers, to more sophisticated engine driven expellers which are shown in the following figure.

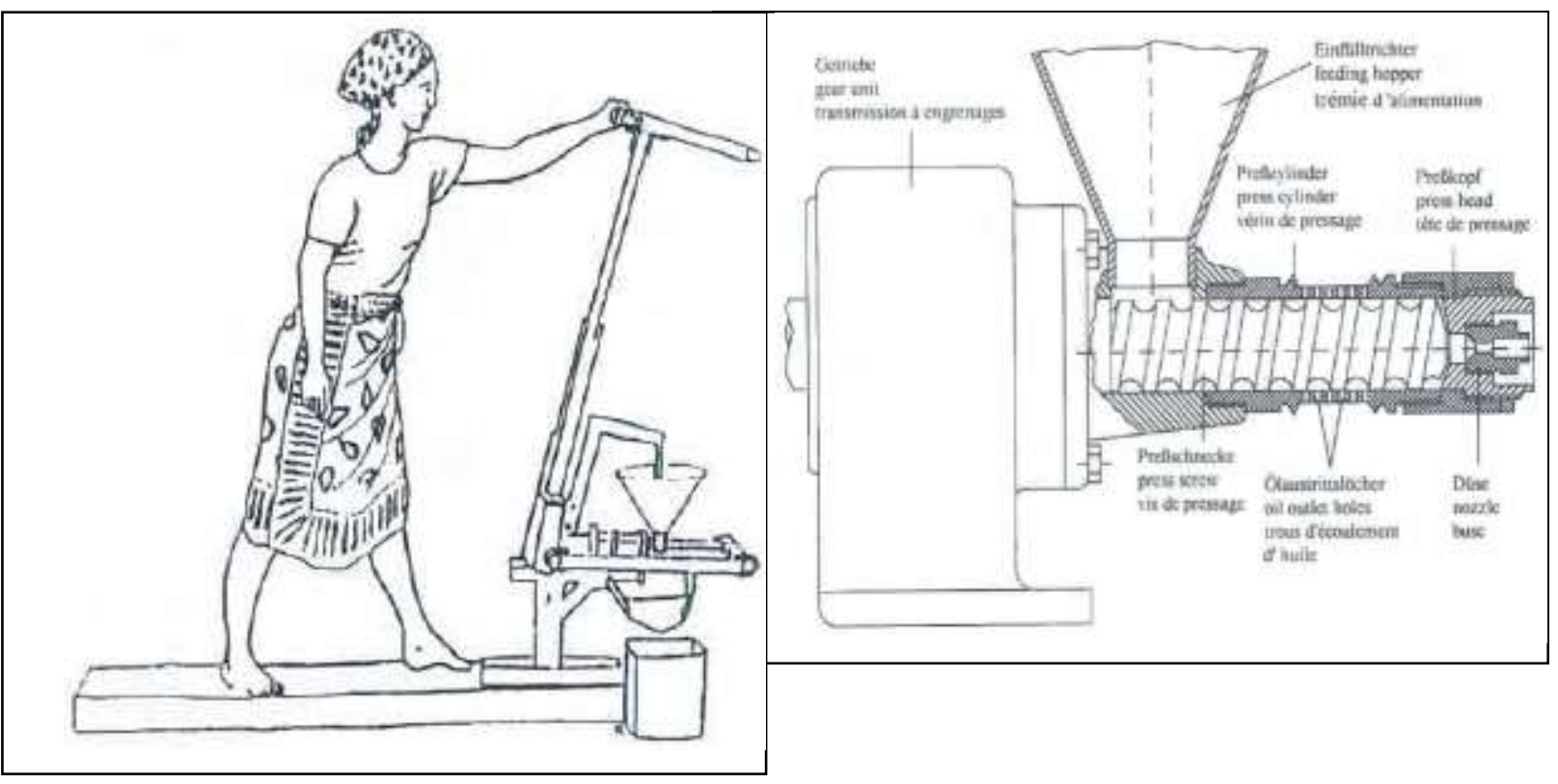

Figure 1. Presser-Expeller Equipments Source: Kurki \& Bachmann (2006)

The availability of the two types of equipment can make poor people to produce their own source of income. Moreover, the hand driven driven expellers are also suitable for areas where electricity are not yet available. On the other hand, for those who are expecting commercialization of the products, the engine driven equipment can help them to reduce the production time thereby increasing their production capacities. The price of the hand driven presser-expeller equipment varies, for example it is around US\$265 in Tanzania (http://journeytoforever.org/biofuel_supply.h tml\#Oilpress).

From every $3 \mathrm{~kg}$ of seeds there is around 1 liter of extracted oil (http://herbalmedicine.philsite.net/tuba-tuba.htm). The pressed cake from the presser-expeller machine can be used as fertilizer due to its nutrient content, i.e. 6\% Nitrogen $(\mathrm{N})$, $2.75 \%$ Phosphor (P), and $0.94 \%$ Potassium $(\mathrm{K})$, which is similar to chicken manure (http://www.jatrophacurcasindia.com/).

Furthermore, the cake can also be used as animal feedstock after being introduced to heat and chemical treatment to detoxify its toxins contents (Aregheore et. al, 2003).

\section{ECONOMIC BENEFITS FROM JATROPHA CURCAS PLANTATION}

An example of economic benefits from Jatropha curcas plantation is taken from the experience of India that has started to cultivate the plant several years ago. The following table shows the summary of 
expenditure and revenue per one hectare of land that comparing the plantation with and without intercropping systems. The calculation is for the land that is already owned by farmers (i.e. no cost for acquiring the land).

Table 4. Potential Income from Jatropha curcas Plantation

\begin{tabular}{|c|c|c|c|c|c|c|}
\hline \multirow[t]{3}{*}{ Year } & \multicolumn{6}{|c|}{ US \$ per hectare per year } \\
\hline & \multicolumn{3}{|c|}{ Without Intercropping } & \multicolumn{3}{|c|}{ With Intercropping } \\
\hline & Expenditure & Revenue & Income & Expenditure & Revenue & Income \\
\hline Year 1 & 545.19 & 33.56 & -511.63 & 545.19 & $1,152.13$ & 606.94 \\
\hline Year 2 & 111.86 & 100.67 & -11.19 & 111.86 & $1,286.36$ & $1,174.50$ \\
\hline Year 3 & 111.86 & 559.29 & 447.43 & 111.86 & $1,677.86$ & $1,566.00$ \\
\hline Year 4 & 111.86 & 894.86 & 783.00 & 111.86 & $2,013.43$ & $1,901.57$ \\
\hline Year 5 & 111.86 & $1,398.21$ & $1,286.36$ & 111.86 & $2,516.78$ & $2,404.93$ \\
\hline
\end{tabular}

Source: Modified from http://www.jatrophabiodiesel.org/economics.php?_divid=menu4

The table shows that by using intercropping system, the income is started to be gained in the first year. Examples of intercropping system are plantation of Jatropha curcas with red and green peppers, tomatoes, water melons, vanilla, mulberry etc. Furthermore, the intercropping has some other advantages as follows.

- Avoid dependency on one crop.

- Reduction the use of fertilizers.

- Possible to recover investment in shorter time.

- Flexibility in the distribution of labours.

- Produce a large variety of useful products.

- Availability of harvest over a longer period of time.

\section{BIODIESEL PRODUCTION FROM JATROPHA CURCAS OIL}

The seeds of Jatropha curcas content from $31 \%$ to $37 \%$ oil that can be used as fuel both in unrefined and refined states. The unrefined oil (straight vegetable oil) has too high viscosity to be used in current diesel engine, therefore there is a need for modifying the engine to cope with the high viscosity. However, there are many chemical processes available to reduce the viscosity. Two scientists, E. Duffy and J. Patrick, discovered in 1853 a simple chemical process to reduce the oil viscosity called transesterification. After the chemical process, the oil is called biodiesel that can be used or blended directly without any diesel engine modifications.

Based on reaction formula (1) that is shown previously, the oils that are extracted from Jatropha curcas seeds react with methanol with the aid of catalyst $\mathrm{NaOH}$ to form methyl ester (biodiesel) and glycerine. The chemical process ends when the glycerine is left on the bottom and the methyl ester is on the top which can be filtered. The standard for biodiesel specification in Indonesia is SNI 04-7182-2006.

There are some existing technologies developed for producing biodiesel. The list of the technologies and their installation costs based on the capacities is presented in the following table. 
Table 5. Biodiesel Production Technology

\begin{tabular}{|l|r|r|}
\hline \multicolumn{1}{|c|}{ Technology } & \multicolumn{1}{c|}{$\begin{array}{c}\text { Capacity } \\
\text { (Tons/year) }\end{array}$} & $\begin{array}{c}\text { Installation } \\
\text { Cost (US\$) }\end{array}$ \\
\hline $\begin{array}{l}\text { Bandung Institute of } \\
\text { Technology }\end{array}$ & 5,000 & $2,000,000$ \\
\hline Campa & 5,000 & $3,000,000$ \\
\hline Lurgi & 50,000 & $13,000,000$ \\
\hline $\begin{array}{l}\text { Biodiesel International } \\
\text { (BDI) }\end{array}$ & 50,000 & $15,000,000$ \\
\hline Conneman & 50,000 & $15,000,000$ \\
\hline
\end{tabular}

Source: Ministry of Industry of Indonesia (2006)
To show the process that occurs in a biodiesel production, following figure shows the flow diagram of the Lurgi Process. The flow diagram shows that in the production of biodiesel, there will be a by product that can has economic value, i.e. glycerine. Glycerine can be purified to be used in pharmaceuticals, cosmetics, and toiletries industries.

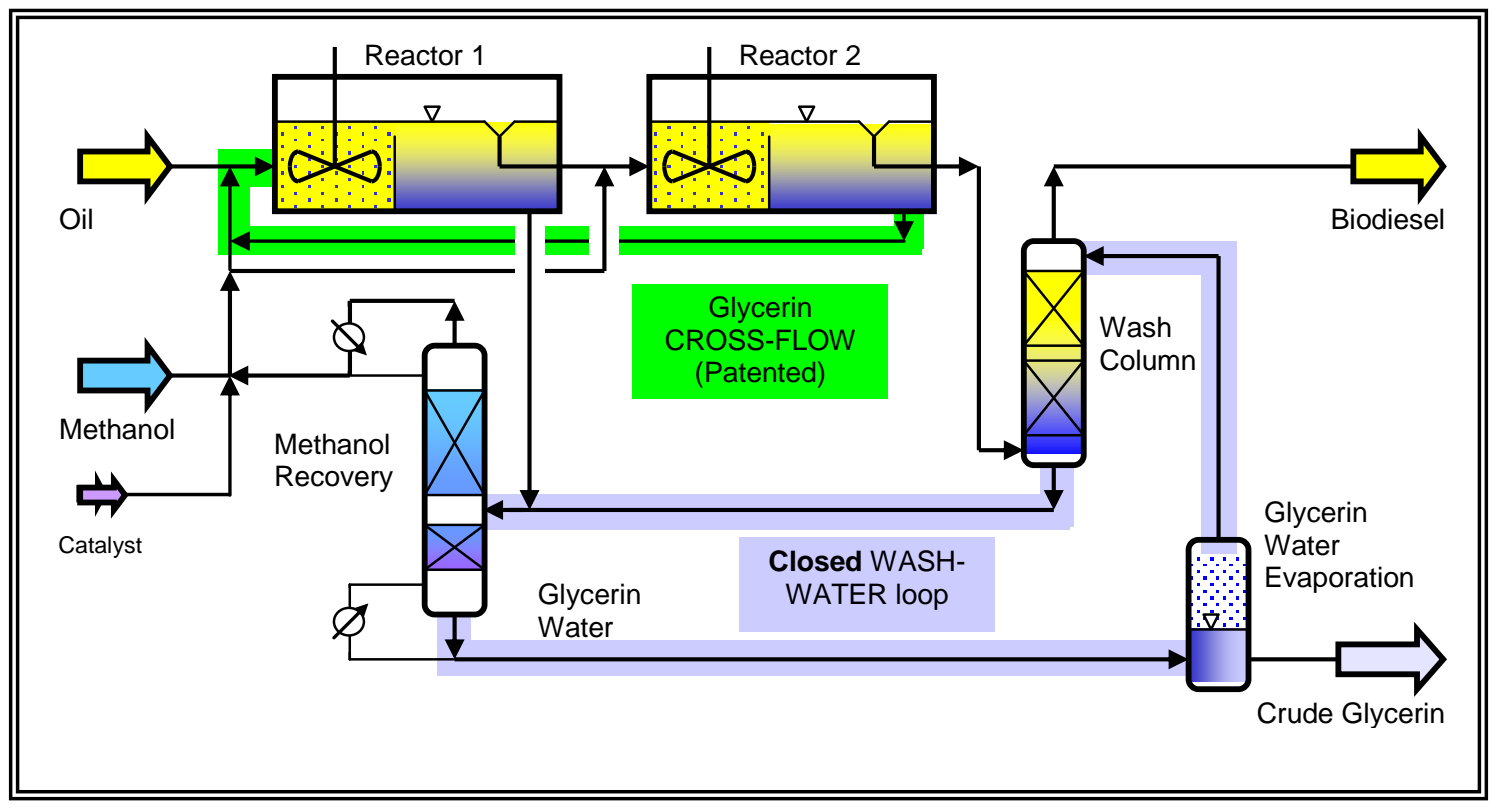

Figure 2. Lurgi Process in Biodiesel Production Source: Kleber (2003)

As for the price of biodiesel, in India based on a pilot project report by Ramesh, D et al (2006), the price of one liter of biodiesel is US\$0.72. This price has taken into account the potential selling of glycerine as a by product. However, another source in India mentioned that from a commercial scale plant the price is US\$0.56, inclusive of taxes and duties (http://www.svlele.com/biodiesel_in_india.h tm). For Indonesia, the price of conventional diesel fuel per liter is US\$0.47, which is still subsidized around US\$0.22 per liter. Therefore, assuming that the biodiesel price is the same as in India, if the Government of Indonesia wants to encourage people using biodiesel, the government has to set the price of the fuel at least the same as the price of conventional diesel fuel. This can only be done by reducing subsidy for the conventional biodiesel.

\section{POTENTIAL OF BIODIESEL FROM JATROPHA CURCAS IN INDONESIA}

Biodiesel potential is calculated by using the data related to biodiesel production from Jatropha curcas from above discussions. 
The data used is the potential of seed production from 2 to 12.5 tons/year/hectare, the oil extracted is one liter per $3 \mathrm{~kg}$ of seeds, and information regarding the area of marginal lands in Indonesia that is around 22 million hectares in 2004. (http://siaphut.dephut.go.id/siaphut/reports/rl ps/penyebaran_lahan_kritis.php).

The result of calculation is the potential of biodiesel from Jatropha curcas plant from 14.7 to 91.7 million kiloliters of biodiesel in 2004. Whereas the total national diesel fuel consumption for that year was around 27.5 million kiloliters (US Embassy - Jakarta, 2006).

\section{ENVIRONMENTAL IMPACT OF USING BIODIESEL}

There are some impacts of using biodiesel to the environment. First, the use of biodiesel can reduce the emission of some air pollutants. Based on information from USEPA (2002), the following table shows the changes of some air pollutant emissions due to biodiesel use.

Table 6. Changes of Some Air Pollutant Emissions due to Biodiesel Use

\begin{tabular}{|l|r|r|r|r|}
\hline $\begin{array}{c}\text { Type of } \\
\text { Biodiesel }\end{array}$ & $\begin{array}{c}\text { Hydro } \\
\text { carbon }\end{array}$ & CO & $\begin{array}{c}\text { Particulate } \\
\text { Matter }\end{array}$ & \multicolumn{1}{c|}{ NOx } \\
\hline B20 & $-20 \%$ & $-12 \%$ & $-12 \%$ & $-2 \%$ to $+2 \%$ \\
\hline B100 & $-67 \%$ & $-48 \%$ & $-47 \%$ & $+10 \%$ \\
\hline
\end{tabular}

$B 20=20 \%$ blend of biodiesel on conventional diesel fuel $B 100=100 \%$ diesel fuel use

Source: US-EPA (2002)

The table shows the changes in some air pollution parameters that are regulated in the United States of America. Almost all parameters show reductions in emissions. There is only one parameter that is not decreasing, i.e. Oxides of Nitrogen (NOx). However, due to the fact that using biodiesel is also reducing the amount of sulphur dioxide emission (US-EPA, 2002), there are some available technologies to deal with the NOx emissions, e.g. the use of catalytic converter. Vehicles with conventional diesel fuel cannot use the converter due to the sulphur dioxide emission that can reduce the effectiveness of the converter.

The second advantage of using biodiesel to the environment is the potential of carbon dioxide $\left(\mathrm{CO}_{2}\right)$ removal from the plantation of the plants for producing biodiesel. For one hectare of Jatropha curcas plantation, can contribute to the reduction of 10 tonnes of $\quad \mathrm{CO}_{2} \quad$ per year. (http://www.tnau.ac.in/tech/swc/evjatropha.p df). Moreover, Bugge (2000) calculated that the use of biofuels from rapeseed oil has a positive $\mathrm{CO}_{2}$ balance, i.e. more $\mathrm{CO}_{2}$ is absorbed by the plantation than is emitted from the plantation and processing. This is an opportunity for developing countries to gain as much as possible the carbon trade through the Clean Development Mechanisms (CDM). Based on an overview of biodiesel and petroleum diesel life cycles (Sheehan et al., 1998), biodiesel use reduces net $\mathrm{CO}_{2}$ emissions by $78.45 \%$ for $\mathrm{B} 100$ and $15.66 \%$ for B20 compared to petroleum diesel.

The third environmental benefit of using biodiesel is energy balance related to the production of biodiesel. Sheehan et al (1998) concludes that biodiesel yields 3.2 units of fuel product energy for every unit of fossil energy consumed. In contrast, the report also states that conventional diesel fuel uses 1.2 units of fossil resources to produce 1 unit of the fuel, i.e. only yields 0.83 units of energy. This means that the production of biodiesel can also preserve un-renewable fossil fuels. 


\section{REFERENCES}

Austrian Biofuels Institute. 2002. Report for the International Energy Agency: The Development of Biodiesel in Germany.

Agarwal AK (2007) Biofuels (Alcohols and Biodiesel) Applications as Fuels for Internal Combustion Engines. Progress in Energy and Combustion Science 33:233-271

Aregheore et. al. 2003. Detoxification of $A$ Toxic Variety of Jatropha Curcas Using Heat and Chemical Treatments, and Preliminary Nutritional Evaluation with Rats. Journal of Natural Science.

Bugge, J. 2000. Rapeseed Oil for Transport: Energy Balance and $\mathrm{CO}_{2}$ Balance.

Haas MJ, Scott KM, Alleman TL, McCormick RL. 2001. Engine Performance of Biodiesel Fuel Prepared from Soybean Soapstock: A High Quality Renewable Fuel Produced from a Waste Feedstock. Energy and Fuels 15:1207-1212

Indonesian Central Bureau of Statistics. 2006. Population and Type of Activities from 2001 to 2005. http://www.bps.go.id/sector/employ/tabl e1.shtml

Indonesian Department of Fishery and Ocean. 2004. Inventory of Islands in Indonesia.

http://www.dkp.go.id/content.php?c=14 61

Indonesian Ministry of Industry. 2006. Masukan untuk Pengembangan Industri Biodiesel di Indonesia.

International Energy Agency. 2006. Key World Energy Statistics.

Janaun J, Ellis N. 2010. Perspectives on Biodiesel as A Sustainable Fuel. Renewable and Sustainable Energy Reviews 14:1312-1320

Journey to Forever. 2006. Oilseed Presses. http://journeytoforever.org/biofuel_supp ly.html\#Oilpress

Kleber, M. 2003. Mississippi Renewable Energy Conference: The Lurgi Biodiesel Technology.
Kurki, A., Bachmann, J. 2006. Oilseed Processing for Small-Scale Producers.

Labeckas G, Slavinskas S (2006) The Effect of Rapeseed Oil Methyl Ester on Direct Injection Diesel Engine Performance and Exhaust Emissions. Energy Conversion and Management 47:19541967

Lapuerta M, Armas O, Fernandez JR. 2008. Effect of Biodiesel Fuels on Diesel Engine Emissions. Progress in Energy and Combustion Science 34:198-223

Mittelbach M, Tritthart P, Junek H. 1985. Diesel Fuel Derived from Vegetable Oils, II: Emission Tests Using Rape Oil Methyl Ester. Energy in Agriculture 4:207-215

Ozsezen AN, Canakci M, Turkcan A, Sayin C. 2009. Performance and Combustion Characteristics of a DI Diesel Engine Fueled with Waste Palm Oil and Canola Oil Methyl Esters. Fuel 88:629-636

Ramesh, D et al. 2006. Production of Biodiesel from Jatropha curcas Oil by Using Pilot Biodiesel Plant

Sahoo PK, Das LM, Babu MKG, Arora P, Singh VP, Kumar NR, Varyani TS. 2009. Comparative Evaluation of Performance and Emission Characteristics of Jatropha, Karanja and Polanga based Biodiesel as Fuel in A Tractor Engine. Fuel 88:1698-1707

Sendzikiene E, Makareviciene V, Janulis P, Makareviciute 2007. Biodegradability of Biodiesel Fuel of Animal and Vegetable Origin. European Journal of Lipid Science Technology 109:493-497

Sheehan et al. 1998. An Overview of Biodiesel and Petroleum Diesel Life Cycles.

Society for Rural Initiative for Promotion of Herbal (SRIPHL). 2006. Jatropha Plantation.

http://www.jatrophabiodiesel.org/

Society for Rural Initiative for Promotion of Herbal (SRIPHL). 2006. Economics of Jatropha

Plantation 
http://www.jatrophabiodiesel.org/econo mics.php?_divid=menu4

SVM Exports. 2006. The Future of Jatropha Has A New Venture. http://www.jatrophacurcasindia.com/

Systemes Solaires No. 161 (2004), No. 167 (2005), and No. 173 (2006). Biofuels Barometer.

Tamil Nadu Agricultural University. 2006. Jatropha Production Technology. http://www.tnau.ac.in/tech/swc/evjatrop ha.pdf

Tan PQ, Hu ZY, Lou DM, Li ZJ. 2012. Exhaust Emissions from A Light Duty Diesel Engine with Jatropha Biodiesel Fuel. Energy 39:356-362

The Philippine Herbal Medicine Site. 2006. Tuba-tuba Plant Seeds (Jatropha) to Biodiesel Fuel. http://herbalmedicine.philsite.net/tuba-tuba.htm

The Pictures of Jatropha curcas Plant. http://jatropha.org/plant/plant-2.htm

The United Kingdom - Biodiesel Filling

Stations. 2006. Technical Details and Standards.

http://www.biodieselfillingstations.co.uk lapprovals.htm

The United Kingdom - National Atmospheric Emissions Inventory. 2006. Emission Factors Database. http://www.naei.org.uk/emissions/select ion.php

The United State Census Bureau. 2006. Total Midyear Population of the World: 1950-2050.

http://www.census.gov/ipc/www/worldp op.html

The United State Embassy - Jakarta. 2006. Petroleum Report Indonesia 2005 2006.

The United State Embassy - Jakarta. 2004. Energy News: Indonesia 2003 Oil Production Drops 8 Percent. http://www.usembassyjakarta.org/econ/ oil-2003-drop.html

The United States Energy Information Administration. 2006. International Energy Price Information. http://www.eia.doe.gov/emeu/internatio nal/prices.html\#Crude

The United States - Environmental Protection Agency (US-EPA). 2002. A Comprehensive Analysis of Biodiesel Impacts on Exhaust Emissions.

Tickell, J. 2000. From the Fryer to the Fuel Tank - The Complete Guide to Using Vegetable Oil as an Alternative Fuel.

USDA, United States Department of Agriculture. 2012(a). Indonesia Biofuels Annual 2012. Global Agricultural Information Network (GAIN) Report No. ID1222

USDA. 2013(a). Indonesia Biofuels Annual 2013. Global Agricultural Information Network (GAIN) Report No. ID1337

USDA. 2012(b). Indonesia Oilseeds and Products Annual 2012. Global Agricultural Information Network (GAIN) Report No. ID1210

USDA. 2013(b). Indonesia Oilseeds and Products Annual 2013. Global Agricultural Information Network (GAIN) Report No. ID1316

USEPA, United States Environmental Protection Agency. 2002 A Comprehensive Analysis of Biodiesel Impacts on Exhaust Emissions [URL: http://www.epa.gov/oms/models/analysi s/biodsl/ p02001.pdf] Accessed on 16th July 2013 